\title{
Corn Yield Intercropped With White Clover as Living Mulch
}

\author{
Marcia Fernanda Franchin Adami ${ }^{1}$, Alcir José Modolo ${ }^{1}$, Paulo Fernando Adami ${ }^{2}$, Christiano Santos Rocha Pitta ${ }^{3}$, \\ Eduardo Roncatto ${ }^{3}$, Vanderson Vieira Batista ${ }^{4} \&$ Luis Cesar Cassol $^{1}$ \\ ${ }^{1}$ Post Graduate Program in Vegetable Production, Technologic University of Paraná, Pato Branco, PR, Brazil \\ ${ }^{2}$ Post graduate Program in Vegetable Production, Technologic University of Paraná, Dois Vizinhos, PR, Brazil \\ ${ }^{3}$ Department of Agronomy, Federal Institute of Paraná Palmas, PR, Brazil \\ ${ }^{4}$ Department of Agronomy, Technologic University of Paraná, Dois Vizinhos, PR, Brazil \\ Correspondence: Vanderson Vieira Batista, Technologic University of Paraná, Dois Vizinhos, PR, Brazil. Tel: \\ 55-469-9900-0618. E-mail: vandersonvbatista@hotmail.com
}

Received: August 15, 2018

Accepted: November 10, $2018 \quad$ Online Published: January 15, 2019

doi:10.5539/jas.v11n2p276

URL: https://doi.org/10.5539/jas.v11n2p276

\begin{abstract}
Brazil southern region edaphoclimatic conditions allow farmers to grow perennial winter legumes. However, at summer, a seasonality occurs in the production of these species allowing the grown of annual crops such as corn. In this way, interference between white clover (Trifolium repens L.) living mulch and corn crop (Zea mays L.) was studied using a clover sward established after one and two growing season in relation to the usual system of corn grown over black oat straw aiming to study the relationships occurring in this intercrop, such as white clover herbicide suppression, competition and its nitrogen effects on corn yield as well as its potential to became perennial after corn harvest. White clover suppression management was established in the main plots and corn nitrogen fertilization $\left(0,60,120,180 \mathrm{~kg} \mathrm{ha}^{-1}\right)$ was performed in the subplots $(4.2 \times 8 \mathrm{~m})$ in a randomized block design with four replications. White clover suppression managements were: (i) partial suppression achieved by mowing the plots at the corn seeding day; (ii) partial suppression achieved by mowing plus chemically broadcast application of 2.4-D; (iii) partial suppression achieved by a chemically broadcast application of glyphosate. Corn grain yields ranged from 3.0 to $12.2 \mathrm{Mg} \mathrm{ha}^{-1}$. Nitrogen input and herbicide management are important elements to reduce white clover competition and increase corn yield. It is possible to manage white clover as living mulch in corn with its full recovery after corn harvest without replanting. Clover with 1 cycle is easier suppressed than perennial clover sward and can be handled in intercropping with corn without affecting grain yield, with ability to resume growth in the next growing season.
\end{abstract}

Keywords: Trifolium repens, competition, suppression, perennial legumes, corn crop management, yield components

\section{Introduction}

Many studies in the southern of Brazil have been addressed to the use of winter legumes as an alternative to reduce nitrogen fertilizer for summer crops, mainly using vetches (Vicia vilosa) (Silva et al., 2007), although, there are few reports about the use of perennial legumes, such as clovers (Trifolium spp), especially in living mulch system to be intercropped with corn (Assmann et al., 2007).

Intercropping systems is an advanced agro technique of cultivation two or more crops in the same space and same time and it is known to make a more efficient use of growth factors as they capture and make a better use of radiant energy (Matusso et al., 2012), available water and nutrients (Sullivan, 2003), decrease soil erosion (Wall et al., 1991), prevent pest and diseases (Culman et al., 2010), suppress weeds (Den Hollander et al., 2007), as well as reduce the use of defensives (Ratnadass et al., 2012) and in the case of legumes, supply N (Assmann et al., 2007; Peoples et al., 1995) and maintain and improve soil fertility (Seran \& Brintha, 2010).

Among the most cereal-legume intercropping system, corn has been recognized as most used specie (Ijoyah, 2012) due to its advanced growth rate, height advantage, and a more widespread rooting system which gives it upper hand in competition with associated legumes (Belel et al., 2014). Moreover, it is one of the most important carbohydrate sources both to human (in the developing countries) and animal feed worldwide due to its high feeding value (Undie et al., 2012). 
In cereal crops, perennial legumes with slow development and growth, such as white and red clover, are suitable for under-sowing (Känkänen \& Eriksson, 2007). In various studies, white and red clover cover crops have produced a residual effect corresponding to between 0 and $90 \mathrm{~kg}$ mineral fertilizer $\mathrm{N} \mathrm{ha}^{-1}$ (Assmann et al., 2007).

Furthermore, characteristics of white clover should allow it to be used successfully as living mulch in corn. White clover is a long-lived, perennial, rhizomatous legume that tolerates frequent defoliation in monoculture (Peterson et al., 1994) or in binary mixture with grass (Kim, 1996) and is suitable for hay or pasture production (Sheaffer et al., 1992) or to be used as a living mulch with corn (Zemenchik et al., 2000). Moreover, the use of white clover as living mulch with corn may turn it perennial, reduce its establishment costs and improve crop-livestock integration systems.

Subjecting white clover to herbicide suppression before corn planting will allow a substantial portion of roots, rhizomes, petioles, and leaflets to be mineralized and provide inorganic $\mathrm{N}$ for corn. Furthermore, white clover does not produce abundant dry matter during hotter periods of the growing season (Hutchinson et al., 1995) and should therefore compete less with corn for limited resources such as water, and to a lesser extent, light and nutrients (Eberlein et al., 1992).

Its persistence may allow the use of herbicides for vegetative control during the corn growth period so that interspecific competition will be limited. White clover left in the field after a summer corn-silage or grain harvest may provide substantial autumn and winter forage production or ground cover to protect the soil. In addition, white clover can provide protein to supplement corn stover when grazed follows grain harvest. Viable meristematic tissue remaining on the rhizomes may allow recovery of white clover to full production following corn harvest.

In this context, this study evaluated a consortium model that combines white clover (Trifoliun repens L.), a perennial winter legumes with a summer corn crop in relation to the usual system of corn grown over black oat straw and seeks to study the relationships occurring in this intercropping, such as white clover herbicide suppression, competition and its nitrogen effects on corn yield as well as its potential to became perennial after corn growth. The information gained could be used to adjust white clover suppression management and thereby improve farm profits and decrease negative impacts on the environment.

\section{Material and Methods}

The experiment was carried out at the Federal Institute of Paraná (IFPR), campus of Palmas, Agricultural Research Station, at 1,115 m above sea level. According to the Köppen classification, the climate is Cfb (IAPAR, 2018). Treatments included corn sowed over black oat straw, clover with 1 cycle, clover 2 cycles mowed and mowed + herbicide 2.4-D with row spacing of $0.7 \mathrm{~m}$ at 70,000 seeds $\mathrm{ha}^{-1}$. White clover and oat herbicide suppression management was established in the main plots and corn nitrogen fertilization $\left(0,60,120,180 \mathrm{~kg} \mathrm{ha}^{-1}\right)$ was performed in the subplots in a randomized block design with four replications. Nitrogen was applied in sidedress on corn at V4 and V8 dividing its rates in equidistant doses using urea as a source ( $45 \%$ of $\mathrm{N})$.

White clover was sown on May, 2013 and 2014, using a no-till seeder and $4 \mathrm{~kg}$ of seed per hectare characterizing what is called clover with 1 and 2 production cycles, respectively. Weed control was carried out manually and the area remained fallow until corn (Hybrid DKB 290 PRO3) seeding in October 2014.

Black oat plots were seeded on May, 2014 with $70 \mathrm{~kg}$ of seed hectare ${ }^{-1}$. In both years, the predecessor culture to clover was soybean. White clover seeds were not inoculated and not made chemical soil correction, which had the following chemical characteristics $(0-20 \mathrm{~cm})$ : $\mathrm{pH}(\mathrm{CaCl} 2) 4.6$; V\% 44; organic matter 64,33 $\mathrm{g} \mathrm{dm}^{-3}$; P-Mehlich $6.35 \mathrm{mg} \mathrm{dm}^{-3}$; $\mathrm{Ca}, \mathrm{Mg}, \mathrm{K}$ and $\mathrm{Al} 4.6 ; 0.7 ; 0.23$ and $0.54 \mathrm{cmol}_{\mathrm{c}} \mathrm{dm}^{-3}$ respectively; $\mathrm{H}+\mathrm{Al} 7.13$ and $\mathrm{CEC}$ of 12.76 $\mathrm{cmol}_{\mathrm{c}} \mathrm{dm}^{-3}$.

At the plots with black oat and white clover with 1 cycle, glyphosate were sprayed at rate of $1080 \mathrm{~g}$ a.i. ha ${ }^{-1}, 30$ days prior corn sowing. At the plots with white clover with 2 production cycles, clover was mow at the soil level at the day of corn sowing. Treatment with mowing $+2.4-\mathrm{D}$, herbicide was sprayed 15 days after mowing with $806 \mathrm{~g}$ i. a ha ${ }^{-1}$.

Corn hybrid DKB 290 PRO3 was sowed on 24 Oct. 2014 with a no-till planter. As a starter fertilizer, we applied 80 $\mathrm{kg} \mathrm{ha}^{-1}$ of $\mathrm{P}_{2} \mathrm{O}_{5}$ in the form of triple superphosphate. Potassium was broadcast applied at sowing, using $200 \mathrm{~kg}$ of $\mathrm{Kcl} \mathrm{ha}^{-1}$.

Corn growth and development were evaluated throughout its cycle in order to better explain the treatments effects on grain yield. Corn plants height were evaluated at 20 and 40 days after its emergence and at tasseling by measuring the distance from the ground to the insertion of the last full developed leaf of 10 plants per plot with a ruler graduated in centimeters. 
To determine corn yield components, 10 ears per plot were evaluated, and the number of grain per row and number of row were registered and weight of thousand grains was assessed by manual counting of 400 grains, weighing and correction of moisture content to $13 \%$, with extrapolation to a thousand-grain weight.

Corn grain was harvested on Apr. 2015 and corn grain yield was determined by hand-collecting corn ears from the two center rows $8 \mathrm{~m}$ long and then passing the ears through a stationary corn thresher. Corn grain yields were adjusted to a moisture concentration of $13 \mathrm{~g} \mathrm{~kg}^{-1}$. Corn populations at grain harvest were determined by counting and recording the number of plants harvested within each plot.

Aboveground clover biomass was measured 30 days before corn sowing, at corn harvest (April 25) and at July 31 to obtain an estimate of competition and regrowth capacity. It is important to emphasize that only alive biomass was collect; under the white clover live tissue, there was a large amount of dead plant material. Living vegetation was hand-harvested from two $0.25-\mathrm{m}^{2}$ quadrats in each plot and oven-dried at $60{ }^{\circ} \mathrm{C}$ until constant weight to determine yield per hectare on a dry-weight basis.

White clover suppression management was established in the main plots and corn nitrogen fertilization $(0,60,120$, $180 \mathrm{~kg} \mathrm{ha}^{-1}$ ) levels was performed in the subplots in a randomized block design with four replications. All data were submitted to analysis of variance and to F-Test to significance level of 0.05 probability through Statygraphics to test the effects of cover crops management, effects of nitrogen levels and management $\mathrm{x}$ nitrogen levels interactions for all measurements. To the variables that showed interaction was deployed each management within the nitrogen levels. When there was no interaction was performed mean comparison test for the managements and regression to nitrogen levels.

\section{Results}

Corn grown over black oat and white clover with 1 cycle showed a similar pattern of development, differing, however, from corn grown over clover with two cycles.

Table 1. Corn plants height $(\mathrm{cm})$ at 20 and 40 days after its emergence and final height in relation to the different cover crops

\begin{tabular}{llll}
\hline \multirow{2}{*}{ Treatment } & \multicolumn{3}{c}{ Height Evaluation periods } \\
\cline { 2 - 4 } & Height 20 DAE & Height 40 DAE & Final Height \\
\hline Black oat + Gly $^{1}$ & $36.79 \mathrm{a}$ & $116.63 \mathrm{a}$ & $247.63 \mathrm{a}$ \\
Clover 1 cycle + Gly $^{1}$ & $36.03 \mathrm{a}$ & $118.74 \mathrm{a}$ & $234.33 \mathrm{a}$ \\
Clover 2 cycle mowed & $22.52 \mathrm{~b}$ & $71.31 \mathrm{~b}$ & $202.75 \mathrm{~b}$ \\
Clover 2 cycle mowed $+2.4-\mathrm{D}^{2}$ & $21.82 \mathrm{~b}$ & $69.71 \mathrm{~b}$ & $200.02 \mathrm{~b}$ \\
\hline
\end{tabular}

Note. ${ }^{123}$ Contracted form of Glyphosate and 2,4-D applied at rates of 1080 and 806 g i.a. ha ${ }^{-1}$ respectively. Means in the columns followed the distinct letters differ by Tukey test $(\mathrm{p} \leq 0.05)$.

When comparing the clover with two productivity cycles in relation to clover with 1 cycle and corn over black oat, there was difference for plant height and development possible explained by a greater competition effect at these treatments.

Corn development was influenced linearly by $\mathrm{N}$ rates at all the evaluated periods. There was lower effect of nitrogen at 20 days after emergence (DAE), due to the short period between nitrogen application and height evaluation. The difference between the treatment without $\mathrm{N}$ and with $180 \mathrm{~kg} \mathrm{~N}^{-1}$ at $40 \mathrm{DAE}$ and final height was of $30 \mathrm{~cm}$ and 54 respectively (Figure 1). 


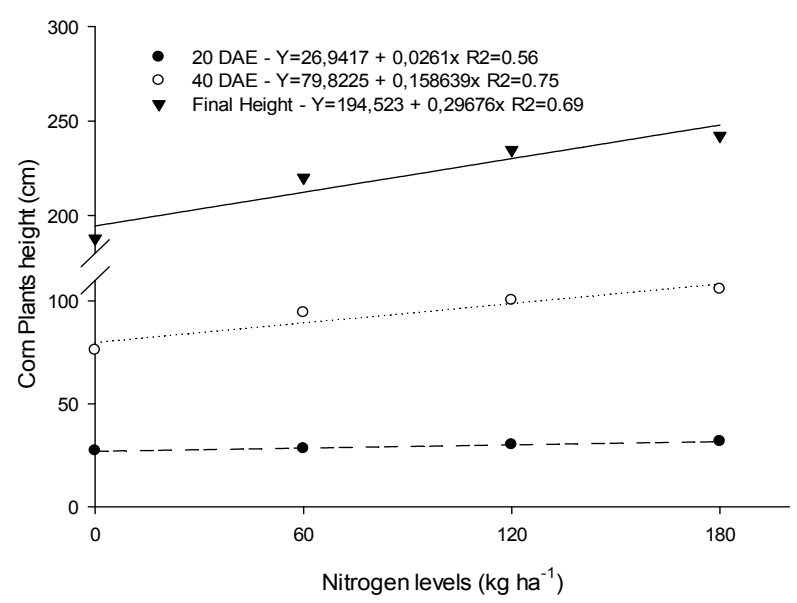

Figure 1. Regression analysis of corn plants height evaluated at 20 and 40 days after emergence and final plant height in relation to four nitrogen levels: $0,60,120$ and $180 \mathrm{~kg} \mathrm{ha}^{-1}$

Similar to the treatments effect on corn plant height, yield components were also affected. There was an interaction between cover crops and nitrogen levels for the number of row per ear and grain per row (Figure 2). Corn grain per ear, weight of thousand grains and grain yield increased linearly as nitrogen was increased to the corn grown over black oat and white clover with 1 cycle.

There was a quadratic answer of corn crop grain per row over white clover of 2 cycles managed with 2,4-D. It is difficult to explain such tendency, once corn over other cover managed answer linearly. Was noticed at this treatment, greater suppression of white clover what in turn, open up space to weed plants which may have competed with corn, especially at higher nitrogen levels, what in turn resulted in lower grain per row.
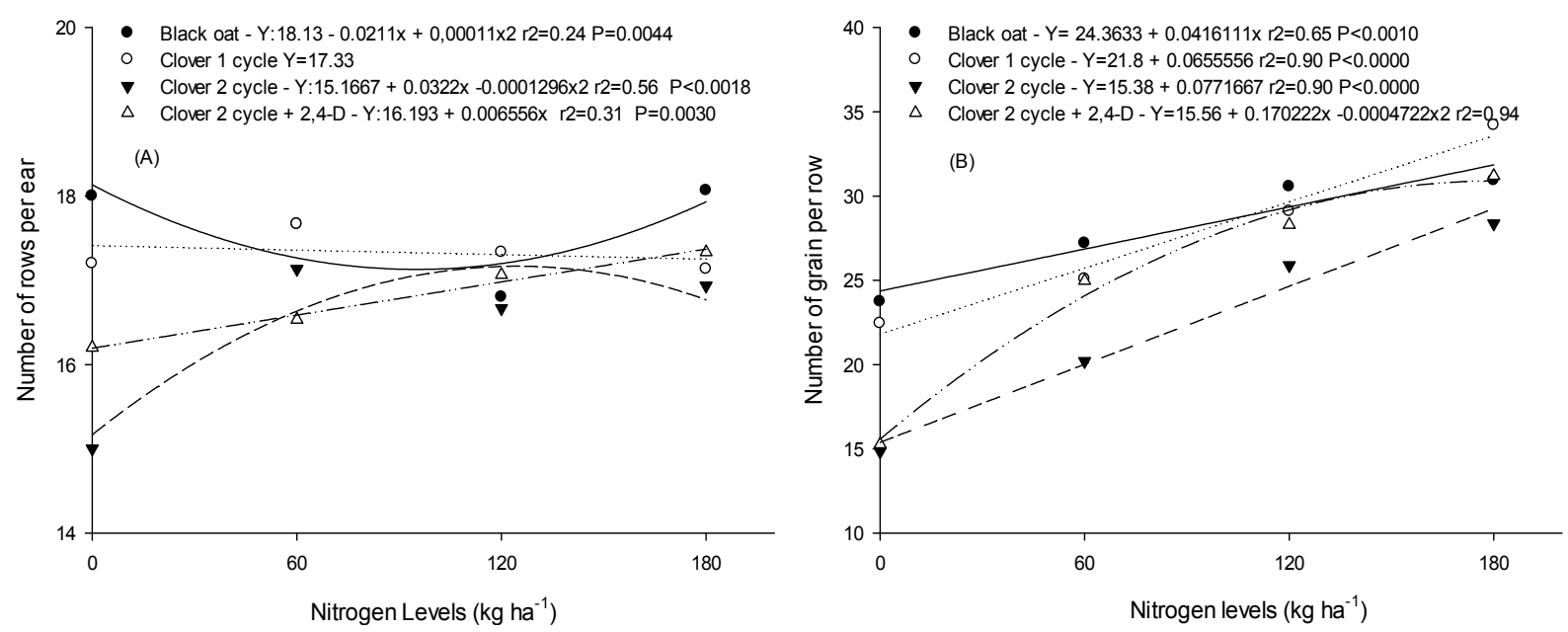

Figure 2. Regression analysis of the number of rows per ear (A) and number of grain per row (B) in relation to four nitrogen levels: $0,60,120$ and $180 \mathrm{~kg} \mathrm{ha}^{-1}$

Regarding to the number of kernels per ear, there was also an interaction between cover crops and nitrogen levels (Figure 3). Corn grown over black oat and clover with 1 cycle showed a linear increase of 0.71 and 1.11 grains/ear per kg of $\mathrm{N}$ applied. These values represent additional 129 and 198 grains per corn ear between the treatment without $\mathrm{N}$ and the treatment with $180 \mathrm{~kg} \mathrm{ha}^{-1}$, respectively. On the other hand, this variable at the treatments with clover of two cycles showed a quadratic effect, possibly limited by the number of rows per ear and kernels per row. 

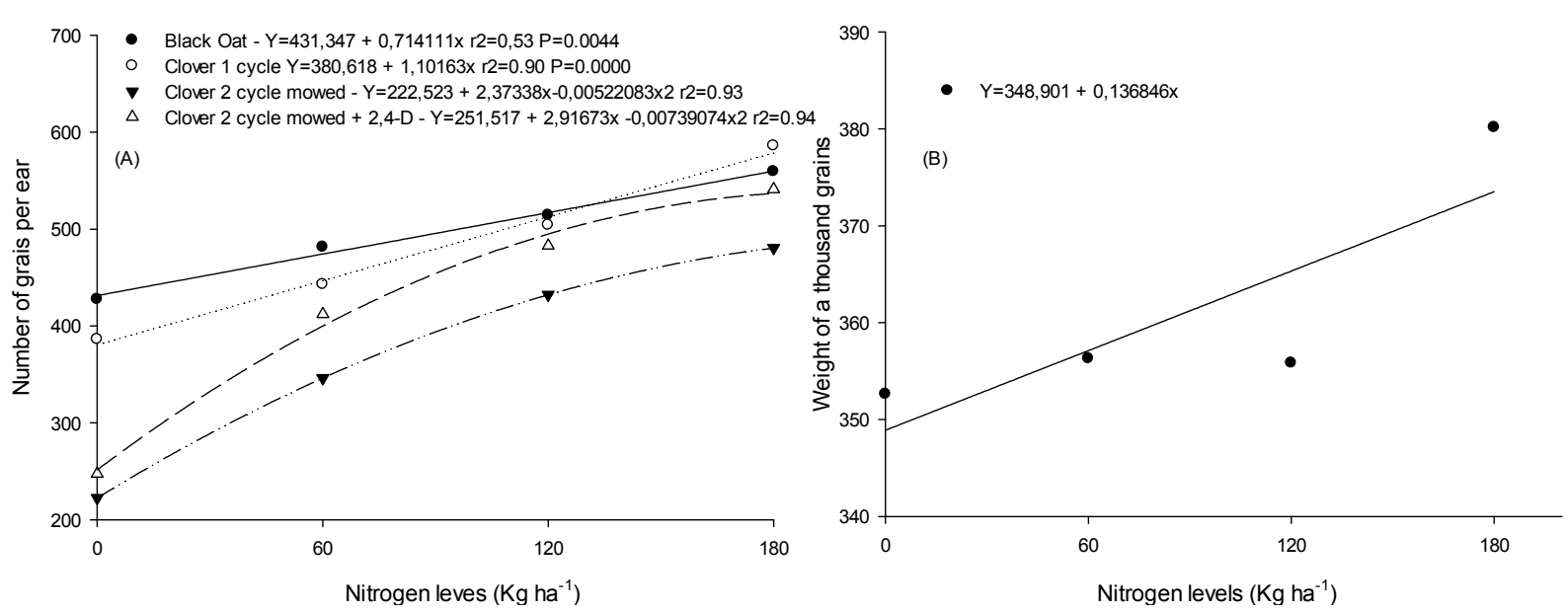

Figure 3. Regression analysis of the number of grain per ear (A) and weight of a thousand grain (B), submitted to four nitrogen levels: $0,60,120$ and $180 \mathrm{~kg} \mathrm{ha}^{-1}$

For the weight of thousand grains (WTG), there was no interaction between cover plants versus nitrogen levels and also there was no effect of different plant cover, with an average of $361 \mathrm{~g}$. However, WTG increased linearly as nitrogen levels increased.

Regarding the corn final plant population (Figure 4A), it is noticed that there was interaction between cover crops and nitrogen levels. Final population of corn planted over black oat and clover with 1 cycle did not differ between $\mathrm{N}$ levels, showing an average of 64.356 and 68.002 plants ha ${ }^{-1}$. Although, corn population planted over clover with two cycles increased linearly ( 95 plants per $\mathrm{kg} \mathrm{N}$ ) as nitrogen levels were increased.
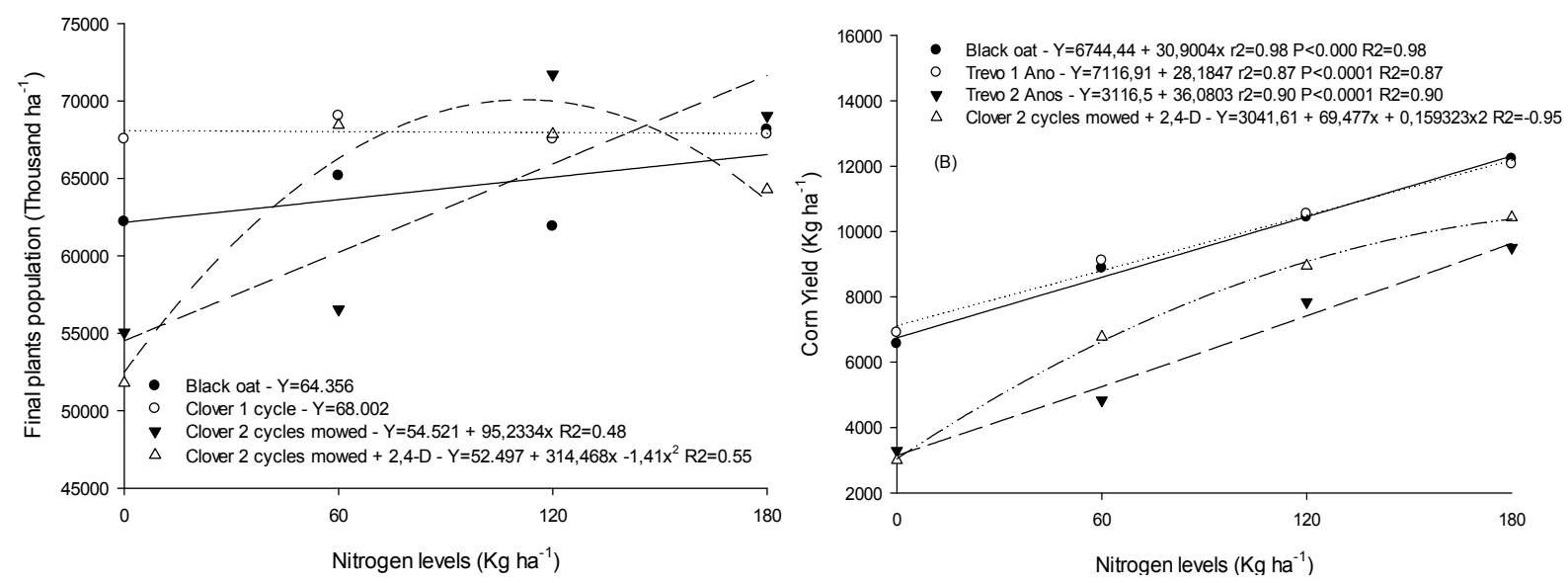

Figure 4. Regression analysis of the final corn plants per hectare (A) and corn yield (B) in relation to the nitrogen levels: $0,60,120$ and $180 \mathrm{~kg} \mathrm{ha}^{-1}$

Regarding grain yield, it was noticed a linear increase as nitrogen rates were increased (Figure 4B). Corn planted over black oat and white clover with one cycle showed yields of 6.744 and $7.116 \mathrm{~kg} \mathrm{ha}^{-1}$ at the treatment without $\mathrm{N}$, and increased 30.9 and $28.18 \mathrm{~kg}$ of grain per kg of $\mathrm{N}$ applied reaching yield of 12.223 and $12.062 \mathrm{~kg} \mathrm{ha}^{-1}$ or still, 45 and $41 \%$ higher than the treatment without nitrogen.

Regarding to the cover crops biomass, at 30 days prior corn sowing, at the corn sowing day (10/24/14) and corn harvesting (04/25/2015), black oat showed an average dry matter value among nitrogen levels of 7.230, 6.540 and $3.124 \mathrm{~kg} \mathrm{ha}^{-1}$ respectively. In the same period, clover with 1 cycle showed a dry matter biomass of 880 (14\% of $\mathrm{DM}), 540$ and $1.424 \mathrm{~kg} \mathrm{ha}^{-1}$. This biomass increased to $2.850 \mathrm{~kg} \mathrm{ha}^{-1}$ on July 31 .

White clover with two cycles mowed and mowed + 2.4-D showed averaged dry matter among nitrogen levels, at the corn sowing day of $3.220 \mathrm{~kg} \mathrm{ha}^{-1}$. At corn harvest day, biomass was of 2.916 and $1.993 \mathrm{~kg} \mathrm{ha}^{-1}$ respectively, differing from each other and being higher then clover with 1 cycle. On July 31, the average biomass levels for 
both treatments was of $4.600 \mathrm{~kg} \mathrm{ha}^{-1}$. Important to emphasize that only live biomass was collect and that there was good amounts of death material underneath. This larger amount of forage is counterbalanced by the smaller corn yield, which was 44 and $42 \%$ lower than the corn planted over clover with 1 cycle, respectively for the treatment without nitrogen and 21 and $15 \%$ less for the treatment with $180 \mathrm{~kg} \mathrm{~N} \mathrm{ha}^{-1}$.

\section{Discussion}

According to Souza et al. (2003), plant height is a genetic trait influenced by the environment, plant population (Brachtvogel et al., 2012), and mainly by the availability of nitrogen in the soil (Repke et al., 2013). It can express plants development and higher plants mean higher growth rate, greater leaf area index and consequently higher photosynthetic capacity and productive potential. On the other hand, lower plants, demonstrates that there was some interference factor on its development.

Clover canopies well established, even with mechanical mowing and/or suppression with 2.4-D (806 g i.a. ha ${ }^{-1}$ ), affected corn plants development, possibly explained by competition between species. Its deep root system had greater ability to compete with corn for light, nutrients and water, affecting its development rate. This statement can be confirmed by the production and accumulation of biomass of clover given at the end of the assessment period at the corn harvest, which was of 2.916 and $1.993 \mathrm{~kg} \mathrm{DM} \mathrm{ha}^{-1}$ respectively for white clover mowed and mowed + 2.4-D.

Corn grains yields ranged from 3 to $12.3 \mathrm{Mg} \mathrm{ha}^{-1}$ and were greatest at the treatment with corn grow over black oat $+180 \mathrm{~kg} \mathrm{~N} \mathrm{ha}^{-1}$. Zemenchik et al. (2000) evaluating a corn + Kura clover intercrop, reported corn grain yield ranged from 7.2 to $11.1 \mathrm{Mg} \mathrm{ha}^{-1}$ with greater yields in both treatments where kura was killed and least where it was suppressed and given no N. Corn grain yields in band-killed (glyphosate applied at $4.0 \mathrm{~kg}$ a.e. ha ${ }^{-1}$ in $61-\mathrm{cm}$ strips centered on the corn row, leaving $15 \mathrm{~cm}$ of untreated kura clover between rows), suppressed $\mathrm{N}$, and suppressed living mulch treatments (glyphosate at $1.7 \mathrm{~kg}_{\text {a.e. }} \mathrm{ha}^{-1}$ ) were 15,30 , and $34 \%$ less than the killed treatment (glyphosate at $\left.3.4 \mathrm{~kg}_{\text {a.e. }} \mathrm{ha}^{-1}\right)$ and 16, 32, and 35\% less than the killed $+\mathrm{N}$ treatment $\left(45 \mathrm{~kg} \mathrm{~N} \mathrm{ha}^{-1}\right)$, respectively.

Corn grain yield grown over clover with 2 cycles, mowed and mowed + 2.4-D showed productivity of 3.116 and $3.041 \mathrm{~kg} \mathrm{ha}^{-1}$ at the treatment without nitrogen. These values were well below the treatments of corn grown over black oat and clover with 1 cycle, reflecting the interspecific competition for light, water and nutrients as reported Ijoyah and Fanem (2012). In the case of clover suppressed with 2.4-D, there was the occurrence of a greater number of weeds, which ended up affecting corn yield. Although, corn yield increased as nitrogen levels were increasing showing a quadratic curve to the treatment mowed + 2.4-D, possibly explained by the lower number of plants per hectare, grains per ear and ears per area.

Based on field observations, Zemenchik et al. (2000) reported that not having competitive from Kura clover plants in close proximity to the corn in the band-killed treatments may have allowed less competition. Moreover, corn whole-plant and grain yields in the band-killed treatment might be improved by sidedressing $\mathrm{N}$.

When comparing clover suppression, it is expected less competition at the treatment with the additional application of 2.4-D, which in fact, presented clover visually herbicide phytotoxicity and growth suppression. It turns out that, with clover suppression, there was room for the occurrence of other weeds, such as crabgrass (Digitaria sanguinalis) and Alexander grass (Uruchloa plantaginea), which ended up competing with corn.

Den Hollander et al. (2007) evaluating clover species weed suppressive ability and competitive ability against the main crop, reported that white clover was found to give the best compromise between adequate weed suppression and mild yield reduction, though also with this species, reduction in corn plant dry weight was still $60 \%$. Martin et al. (1999) also reported delays in the emergence and development of corn plants when intercropping with clover.

Among plants competition for nutrients, nitrogen plays an important role and there were significant differences among treatments. According to Oliveira and Caires (2003), slow initial growth, a yellowish-green colour of the leaves, and the premature senescence of the lower leaves are the principal symptoms of nitrogen deficiency in corn. The discoloration usually commences at the tip of the leaf and progresses along the midrib. Moreover, $\mathrm{N}$ deficiency slows cell division and expansion of the corn growth meristems, resulting in a reduction in leaf area and plant size, with negative effects on photosynthesis and grain yield.

Furthermore, according to Fancelli and Dourado-Neto (2000), corn plants have their production potential defined since its initial development phase. These authors reported that, although the initial phase of corn development (up to three leaves) does not have a great capacity to absorb large quantities of $\mathrm{N}$, due to its small size, high levels of soil mineral $\mathrm{N}$ during this stage appear to be important in order to obtain high grain yields. Moreover, 
the authors stated that the number of rows of corn ear are established before the appearance of the fourth leaf, when the production potential is defined.

Yamada (1996) reports that $\mathrm{N}$ deficiency in the initial stage of corn development compromises plant development and reduce the number of ears eggs, thereby reducing production. Further, according Pöttker and Wiethölter (2004), if not limited by other factors, the greater $\mathrm{N}$ availability increases the potential of the plant to set greater number and weight of grains per spike.

Oliveira and Caires (2003) also reported that the increase in $\mathrm{N}$ levels (0 to $\left.120 \mathrm{~kg} \mathrm{ha}^{-1}\right)$ increased linearly the number of grains per ear $(\hat{\mathrm{Y}}=501.5+0.26 \mathrm{x})$, weight of thousand grains $(\hat{\mathrm{Y}}=356.0+0.20 \mathrm{x})$ and corn yield $(\hat{\mathrm{Y}}=$ $6595.00+15.59 \mathrm{x})$. Amaral Filho et al. (2005) also reported that nitrogen increase from zero to $150 \mathrm{~kg} \mathrm{ha}^{-1}$ provided the highest number of grains per ear $(\mathrm{Y}=485.45+0.359 \mathrm{x})$ and weight of thousand grains with positive effects on grain yield. Differences on climatic conditions after $\mathrm{N}$ appliance may explain such results.

Zimmermann (2001), working with corn hybrids in irrigated no-tillage system, with a population of 65.741 plants $\mathrm{ha}^{-1}$, reported 450 grains per ear and weight of thousand grains of 310.68 grams. Higher capacity of development and start-up of corn plants helped them to overcome the competition imposed by white clover.

Similarly, clover used only for soil coverage, can affect corn plantability due to the presence of large amounts of biomass, limiting the depth of seed deposition resulting in lower plant stand, as observed at the treatment with clover with 2 cycles, impairing corn yield potential (Trogello et al., 2013).

Silva et al. (2007) studying the cultivation of corn in succession to vetch, also reported that the nitrogen applied in sidedress in corn, increases its yield. On average, corn grown on vetch as a preceding crop showed yields $75 \%$ higher $\left(7.7 \mathrm{tha}^{-1}\right)$ than the treatment without nitrogen $\left(4.4 \mathrm{t} \mathrm{ha}^{-1}\right)$.

According to Sangoi and Almeida (1994), to produce 1 ton of grain, corn needs to absorb between 20 to $28 \mathrm{~kg} \mathrm{~N}$ $\mathrm{ha}^{-1}$. Thus, considering a yield of seven tons, corn would require at least absorption of $140 \mathrm{~kg} \mathrm{~N} \mathrm{ha}^{-1}$. Furthermore, these yields may be explained by the high capacity of the soil to provide nitrogen to plants, the release of $\mathrm{N}$ from crop residues as well as the suitable climatic conditions during the crop cycle.

Assmann et al. (2007), reported that corn plots grown after grazed clover showed higher soil nitrate contents at a depth of $0-5 \mathrm{~cm}$ compared to those plot previously cultivated with black oat, indicating a better supply of nitrogen as a result of the previous clover crop presence.

Fisher and Burrill (1993), evaluating corn planted at different densities and planting arrangements into a narrow band tilled in the clover also reported clover interference and corn yields reduction from 12 to $39 \%$. However, when corn row width was reduced from 0.76 to $0.38 \mathrm{~m}$, competition among corn plants declined; they became more vigorous and clover suppressive and reached even higher yields than conventional (no mulch) corn in 0.76 $\mathrm{m}$ rows. Similarly, sweet corn planted at a range of densities into clover mulch killed by atrazine $\left(1.5 \mathrm{~kg} \mathrm{a}^{\mathrm{e}}\right.$. ha $\left.{ }^{-1}\right)$ yielded more in equidistant planting than in wide $(0.76 \mathrm{~m})$ rows.

A near equidistant corn planting arrangement can be a low-input alternative to achieve season-long clover suppression and thus minimize clover's competition with the intercropped corn. Furthermore, the authors recommend season-long suppression through multiple herbicide or mechanical treatments in a white clover (Trifolium repens L.) sweet corn living mulch system.

Martin et al. (1999) evaluating different methods of white clover suppression in intercropping with corn, reported that where only one method of mulch suppression was used (either roto-till or herbicide), corn yields in plots with living mulch were reduced by 39 to $72 \%$ relative to control plots. In both years, corn yields were higher at $115 \mathrm{~kg} \mathrm{~N} \mathrm{ha}^{-1}$ than at $0 \mathrm{~kg} \mathrm{~N} \mathrm{ha}^{-1}$. Corn control treatment (conventional tillage and herbicide applications) yielded $11.583 \mathrm{~kg} \mathrm{ha}^{-1}$, significantly more than $6.844 \mathrm{~kg} \mathrm{ha}^{-1}$ in the combined herbicide (glyphosate at $1.5 \mathrm{~kg}$ a.e. $\mathrm{ha}^{-1}$ plus atrazine at $1.1 \mathrm{~kg}$ a.e. $\mathrm{ha}^{-1}$ ) and rototilled treatment.

Eberlein et al. (1992) studding corn growth in an alfalfa living mulch reported that grain yields in the partial suppression treatment (application of atrazine) were reduced in 55\% when compared with the total suppression-tillage treatment (glyphosate followed by atrazine). Furthermore, when alfalfa was not suppressed, corn grain yields were reduced by $63 \%$ or more under irrigated conditions and by $96 \%$ or more under no irrigated conditions. Studies reported decline in corn yield as a result of competition for water, and to a lesser extent, light and nutrients (Eberlein et al., 1992; Zemenchik et al., 2000).

These results demonstrate the white clover interspecific ability to compete with corn in intercropped systems and emphasize the need for greater suppression with the use of different herbicides in order to allow good corn growth and yield, especially in perennial clover sward. 
White clover dry matter numbers are important because despite the need for nitrogen application to reach better corn yields, white clover grown in consortium with corn shows at the corn harvest time (March/April) a full development, promoting mulching, weed suppression, biological nitrogen fixation and offering quality forage at a time of the year in which the summer species are unproductive and winter forage still have to be established or it is in early development, having all the fall and winter to produce pasture and biomass to the productive system.

\section{Conclusion}

Clover with 1 cycle is easier suppressed and can be handled in intercropping with corn without affecting grain yield, with ability to resume growth in the next growing season. Although, perennial clover sward has greater ability to compete with corn and show higher herbicide tolerance, which difficult its management in intercropping systems. We conclude affirming that a correct monitoring and management of white clover is necessary in order to maintain a high yield in intercropped systems since corn yields were affected by treatment with clover with two productive cycles.

\section{References}

Amaral Filho, J. P. R., Fornasieri Filho, D., Farinelli, R., \& Barbosa, J. C. (2005). Espaçamento, densidade populacional e adubação nitrogenada na cultura do milho. Revista Brasileira de Ciência do Solo, 29, 467-473. https://doi.org/10.1590/S0100-06832005000300017

Assmann, T. S., Assmann, A.L., Soares, A. B., Cassol L. C., Giasson, M. S., \& Giasson, N. F. (2007). Fixação biológica de nitrogênio por plantas de trevo (Trifolium spp) em sistema de integração lavoura-pecuária no Sul do Brasil. Revista Brasileira de Zootecnia, 36, 1435-1442. https://doi.org/10.1590/S1516-3598200700 0600029

Belel, M. D., Halim, R. A., Rafii, M. Y., \& Saud, H. M. (2014). Intercropping of corn with some selected legumes for improved forage production: A Review. Journal of Agricultural Science, 6, 1-15. https://doi.org/10.5539/ jas.v6n3p48

Brachtvogel, E. L. B., Pereira, F. R. S., Cruz, S. C. S., Abreu, M. L. A., \& Bicudo, S. J. (2012). População, arranjo de plantas uniforme e a competição intraespecífica em milho. Revista Trópica: Ciências Agrárias e Biológicas, 6, 75-85.

Culman, S. W., DuPont, S. T., Glover, J. D., Buckley, D. H., Fick, G. W., Ferris, H., \& Crews, T. E. (2010). Long-term impacts of high-input annual cropping and unfertilized perennial grass production on soil properties and belowground food webs in Kansas, USA. Agriculture, ecosystems \& environment, 137(1-2), 13-24. https://doi.org/10.1016/j.agee.2009.11.008

Den Hollander, N. G., Bastiaans, L., \& Kropff, M. J. (2007). Clover as a cover crop for weed suppression in an intercropping design II. Competitive ability of several clover species. European Journal of Agronomy, 26(2), 104-112. https://doi.org/10.1016/j.eja.2006.08.005

Eberlein, C. V., Sheaffer, C. C., \& Oliveira, V. F. (1992). Corn growth and yield in an alfalfa living mulch system. Journal of Production Agriculture, 5(3), 332-339. https://doi.org/10.2134/jpa1992.0332

Fancelli, A. L., \& Dourado-Neto. D. (2000). Produção de milho (p. 360). Guaíba: Agropecuária.

Fisher, A., \& Burrill, L. (1993). Managing interference in a sweet corn-white clover living mulch system. American Journal of Alternative Agriculture, 8(2), 51-56. https://doi.org/10.1017/S0889189300004975

Hutchinson, K. J., King, K. L., \& Wilkinson, D. R. (1995). Effects of rainfall, moisture stress, and stocking rate on the persistence of white clover over 30 years. Australian Journal of Experimental Agriculture, 35(7), 1039-1047. https://doi.org/10.1071/EA9951039

Instituto Agronômico do Paraná (IAPAR). (2010). Retrieved from http://www.iapar.br/modules/conteudo/ conteudo.php?conteudo $=890$

Ijoyah, M. O. (2012). Review of intercropping research on cereal-vegetable based cropping system. Scientific Journal of Crop Science, 1(3), 55-62.

Ijoyah, M. O., \& Fanen, F. T. (2012). Effects of different cropping pattern on performance of maize-soybean mixture in Makurdi. Scientific Journal of Crop Science, 1(2), 39-47.

Känkänen, H., \& Eriksson, C. (2007). Effects of undersown crops on soil mineral N and grain yield of spring barley. European Journal of Agronomy, 27(1), 25-34. https://doi.org/10.1016/j.eja.2007.01.010 
Kim, B. W. (1996). Kura clover development and performance of kura clover/grass mixtures (Ph.D. Diss., University of Wisconsin, Madison).

Matusso, J. M. M., Mugwe, J. N., \& Mucheru-Muna, M. (2012). Potential role of cereal-legume intercropping systems in integrated soil fertility management in smallholder farming systems of sub-Saharan Africa Research. Journal of Agriculture and Environmental Management, 3(3), 162-174.

Martin, R. C., Greyson, P. R., \& Gordon, R. (1999). Competition between corn and a living mulch. Canadian Journal of Plant Science, 79(4), 579-586. https://doi.org/10.4141/P98-089

Oliveira, J. M. S., \& Caires, E. F. (2003). Adubação nitrogenada em cobertura para o milho cultivado após aveia preta no sistema plantio direto. Acta Scientiarum. Agronomy, 25(2), 351-357.

Peoples, M. B., Herridge, D. F., \& Ladha, J. K. (1995). Biological nitrogen fixation: An efficient source of nitrogen for sustainable agricultural production? Plant and Soil, 174(1-2), 3-28. https://doi.org/10.1007/ BF00032239

Peterson, P. R., Sheaffer, C. C., Jordan, R. M., \& Christians, C. J. (1994). Responses of kura clover to sheep grazing and clipping: I. Yield and forage quality. Agronomy Journal, 86(4), 655-660. https://doi.org/10.2134/ agronj1994.00021962008600040013x

Pöttker, D., \& Wiethölter, S. (2004). Épocas e métodos de aplicação de nitrogênio em milho cultivado no sistema plantio direto. Revista Ciência Rural, 34, 1015-1020. https://doi.org/10.1590/S0103-84782004000400007

Ratnadass, A., Fernandes, P., Avelino, J., \& Habib, R. (2012). Plant species diversity for sustainable management of crop pests and diseases in agroecosystems: A review. Agronomy for Sustainable Development, 32(1), 273-303. https://doi.org/10.1007/s13593-011-0022-4

Repke, R. A., Cruz, S. J. S., Silva, C.J., Figueiredo, P. G., \& Bicudo, S. J., (2013). Eficiência da Azospirillum brasilense combinada com doses de nitrogênio no desenvolvimento de plantas de milho. Revista Brasileira de Milho e Sorgo, 12, 214-226. https://doi.org/10.18512/1980-6477/rbms.v12n3p214-226

Sangoi, L., \& Almeida, M. L. (1994). Doses e épocas de absorção de nitrogênio para a cultura do milho em um solo com alto teor de matéria orgânica. Pesquisa Agropecuária Brasileira, 29, 13-24.

Seran, T. H., \& Brintha, I. (2009). Biological and economic efficiency of radish (Raphanus sativus L.) intercropped with vegetable amaranthus (Amaranthus tricolor L.). Open Horticulture Journal, 2(1), 17-21. https://doi.org/10.2174/1874840600902010017

Sheaffer, C. C., Marten, G. C., Jordan, R. M., \& Ristau, E. A. (1992). Forage potential of kura clover and birdsfoot trefoil when grazed by sheep. Agronomy Journal, 84(2), 176-180. https://doi.org/10.2134/agronj1992.00 021962008400020010x

Silva, P. R. F., Silva, A. A. D., Argenta, G., Luizstrieder, M., \& Forsthofer, E. L. (2007). Manejo da ervilhaca comum (Vicia sativa L.) para cultivo do milho em sucessão, sob adubação nitrogenada. Revista Brasileira de Milho e Sorgo, 6, 50-59. https://doi.org/10.18512/1980-6477/rbms.v6n1p50-59

Souza, L. C. F., Gonçalves, M. C., Sobrinho, T. A., Fedatto, E., Zanon, G. D., \& Hasegawa, E. K. B. (2003). Culturas antecessoras e adubação nitrogenada na produtividade de milho em plantio direto irrigado. Revista Brasileira Milho e Sorgo, 2, 55-62. https://doi.org/10.18512/1980-6477/rbms.v2n2p44-51

Trogello, E., Modolo, A. J., Scarsi, M., Silva, C. L., Adami, P. F., \& Dallacort, R. (2013). Manejos de cobertura vegetal e velocidades de operação em condições de semeadura e produtividade de milho. Revista Brasileira de Engenharia Agrícola e Ambienta, 17, 796-802. https://doi.org/10.1590/S1415-43662013000700015

Undie, U. L., Uwah, D. F., \& Attoe, E. E. (2012). Effect of intercropping and crop arrangement on yield and productivity of late season Maize/soybean mixtures in the humid environment of South Southern Nigeria. Journal of Agricultural Science, 4(4), 37. https://doi.org/10.5539/jas.v4n4p37

Wall, G. J., Pringle, E. A., \& Sheard, R. W. (1991). Intercropping red clover with silage corn for soil erosion control. Canadian Journal of Soil Science, 71(2), 137-145. https://doi.org/10.4141/cjss91-013

Yamada, T. (1996). Adubação nitrogenada do milho: quanto, como e quando aplicar. Piracicaba, Informações Agronômicas, 74(1).

Zemenchik, R. A., Albrecht, K. A., Boerboom, C. M., \& Lauer, J. G. (2000). Corn Production with Kura Clover as a Living Mulch. Agronomy Journal, 92(4), 698-705. https://doi.org/10.2134/agronj2000.924698x 


\section{Copyrights}

Copyright for this article is retained by the author(s), with first publication rights granted to the journal.

This is an open-access article distributed under the terms and conditions of the Creative Commons Attribution license (http://creativecommons.org/licenses/by/4.0/). 